\title{
Nutritional Factors, DNA Methylation, and Risk of Type 2 Diabetes and Obesity: Perspectives and Challenges
}

\author{
Luca Parrillo 1,2过, Rosa Spinelli ${ }^{1,2}$, Antonella Nicolò ${ }^{1,2}$, Michele Longo ${ }^{1,2}{ }^{1,}$, Paola Mirra ${ }^{1,2}$, \\ Gregory Alexander Raciti ${ }^{1,2} \mathbb{D}$, Claudia Miele ${ }^{1,2, *}$ and Francesco Beguinot ${ }^{1,2, *}$ \\ 1 Department of Translation Medicine, Federico II University of Naples, 80131 Naples, Italy; \\ lparrillo@alice.it (L.P.); spinelli.rossella@gmail.com (R.S.); antonellan43@gmail.com (A.N.); \\ mi_longo@libero.it (M.L.); paolamirra06@gmail.com (P.M.); gregoryraciti@gmail.com (G.A.R.) \\ 2 URT Genomic of Diabetes, Institute of Experimental Endocrinology and Oncology, \\ National Research Council, 80131 Naples, Italy \\ * Correspondence: c.miele@ieos.cnr.it (C.M.); beguino@unina.it (F.B.); \\ Tel.: +39-081-746-3248 (C.M. \& F.B.)
}

Received: 20 May 2019; Accepted: 17 June 2019; Published: 19 June 2019

\begin{abstract}
A healthy diet improves life expectancy and helps to prevent common chronic diseases such as type 2 diabetes (T2D) and obesity. The mechanisms driving these effects are not fully understood, but are likely to involve epigenetics. Epigenetic mechanisms control gene expression, maintaining the DNA sequence, and therefore the full genomic information inherited from our parents, unchanged. An interesting feature of epigenetic changes lies in their dynamic nature and reversibility. Accordingly, they are susceptible to correction through targeted interventions. Here we will review the evidence supporting a role for nutritional factors in mediating metabolic disease risk through DNA methylation changes. Special emphasis will be placed on the potential of using DNA methylation traits as biomarkers to predict risk of obesity and T2D as well as on their response to dietary and pharmacological (epi-drug) interventions.
\end{abstract}

Keywords: type 2 diabetes; obesity; DNA methylation; nutritional factors; caloric restriction; high-fat feeding; epigenetic biomarker; personalized medicine; prevention; epigenetic drugs

\section{Introduction}

Obesity and type 2 diabetes (T2D) are responsible for a major reduction in life expectancy and quality of life, increasing healthcare costs. The incidence of obesity and T2D continues to rise and represents a major public health problem. While a genetic component undoubtedly plays a role in determining individual susceptibility to these traits, the genetic loci identified by genome-wide association studies (GWASs) only explain a small fraction of the heritability of these disorders (less than $2 \%$ for obesity and $5-10 \%$ for T2D) [1,2]. Some studies have led to the conclusion that genetic factors only marginally contribute to obesity and T2D development and transmission within families. Indeed, known polymorphisms have little impact on current strategies to predict obesity and T2D, even when multiple genes are simultaneously taken into account through risk algorithms. Thus, genetic studies have so far left the issue of how metabolic disorders are transmitted unsolved. These low heritability estimates, along with the dramatic increase in their worldwide prevalence, suggest a major role of lifestyle factors in these diseases [3].

Epigenetics is the study of inheritable and reversible phenomena that modulate gene function without affecting the genome sequence [4]. It represents a logical interface between the genome and environment which shapes T2D and obesity risk and may help explaining the "missing heritability" [5]. 
The two main epigenetic mechanisms underlying metabolic disorders are DNA methylation and histone modifications. Histone modifications include a series of complex post-translational changes such as methylation (mono-, di-, and tri-methylation), acetylation, and SUMOylation. Post-translational changes in histone proteins can alter the chromatin conformation and gene regulation, contributing thus to the metabolic disease phenotype. Their influence on the development of obesity and T2D has been well-described elsewhere [6], and will not be covered in the present review, which is specifically focused on DNA methylation.

The current epidemic of obesity and T2D is mainly due to the current unhealthy lifestyle and nutrition [7]. As one of the primary contributors, dietary imbalances, either undernutrition or overnutrition (both during the prenatal or postnatal life), lead to epigenetic reprogramming which is associated to increased T2D and obesity incidence [8]. For instance, it has been shown that high-fat feeding induces distinctive changes in the mouse epigenome that can be transgenerationally transmitted $[9,10]$. This treatment also alters the plasticity of DNA methylation in low birth weight human subjects [11]. Interestingly, suboptimal caloric intake during the early stages of development (pregnancy or lactation) can disturb the correct allocation of epigenetic marks, increasing the risk of obesity and T2D in the offspring [12]. In this regard, an unbalanced maternal diet may also impact the early establishment of the fetal and neonatal microbiome, leading to specific epigenetic signatures that may potentially predispose to the development of late-life obesity and T2D, as described in [13]. Consistently, adequate nutrition enables proper DNA methylation of obesity and T2D genes and reduces disease risk [14]. In mice, 5-month treatment with a high-fat diet (HFD) intake caused hypermethylation of the Hoxa5 gene promoter in visceral fat. HFD replacement with a standard chow diet is accompanied by simultaneous improvement of the metabolic phenotype and rescue of normal methylation levels at Hoxa5 [15]. All together, these findings have uncovered the capacity of epigenetics to adaptively respond to different nutritional conditions and suggest that targeting epigenetic plasticity may, in the future, offer novel and realistic opportunities to prevent and treat obesity and T2D. In addition, novel evidence now indicates that, in humans, epigenetic changes may represent potential biomarkers predicting individual lifetime risk of obesity and T2D before the development of the disease phenotype [16].

In this review, we will focus on DNA methylation and its potential role in mediating the risk of metabolic disorders caused by unhealthy nutrition. The potential use of DNA methylation marks in the evaluation of disease risk and efficacy of intervention will also be discussed.

\section{DNA Methylation}

DNA methylation is the most widely studied epigenetic mark and is well conserved among most plant, animal, and fungal models [17]. In mammals, it is based on covalent addition of methyl groups to DNA bases. Three conserved enzymes, DNA methyltransferase 1 (DNMT1), DNMT3A, and DNMT3B, are responsible for its occurrence and maintenance and are essential for normal development. Among these, DNMT1 is responsible for the maintenance of a methylation profile that will be conserved through cellular duplication, whereas DNMT3A and DNMT3B are de novo methyltransferases and are important for DNA methylation at the early embryonic stage [18].

DNA methylation marks mainly occur at the $5^{\prime}$ position of the cytosine residues of cytidine-guanine dinucleotides ( $\mathrm{CpG}$, where $\mathrm{p}$ indicates the phosphate group between the two nucleotides). Clustered $\mathrm{CpG}$ dinucleotides forming dense repeat sequences in the genome are termed $\mathrm{CpG}$ islands. Islands are located especially in promoter regions. However, they can also be found in intragenic and enhancer regions [19]. Many studies have revealed that DNA methylation also occurs at sites other than the CpG sequences (non-CpG methylation). Non-CpG methylation has been suggested to be prevalent in human embryonic stem cells and in the brain. However, its functional significance in the mammal genome is poorly understood and will not be further discussed here [20].

DNA methylation is associated with either gene repression or activation depending on the location where it occurs. Generally, DNA methylation in regions near the transcription start site 
and in the enhancer regions suppresses gene expression [21]. The transcriptional suppression by DNA methylation involves inhibition of transcriptional activation factor binding or recruitment of transcription inhibiting factors to these regions [22]. Gene body methylation rather correlates to gene expression and may prevent a spurious transcript initiation from DNA repetitive elements or alternative promoters [23].

Cytosine methylation $(5 \mathrm{mC})$ has long been considered a stable epigenetic modification capable of surviving meiosis. However, $5 \mathrm{mC}$ can be converted back to cytosine by either passive or active demethylation [24]. Passive demethylation can be caused by the inhibition of DNMT1 during cell replication [25], while the active DNA demethylation is catalyzed by DNA demethylases termed ten-eleven translocation (TET) proteins. These enzymes convert 5-methylcytosine to 5-hydroxymethylcytosine and promote a locus-specific reversal of the DNA methylation [26,27].

There is broad evidence indicating that DNA methylation is essential for mammalian development and plays an important role in gene silencing, in protection against spurious repetitive element activity, in genomic stability during mitosis, and in parent-of-origin imprinting [28]. Modulation of DNA methylation is crucial in many biological processes. Hematopoiesis represents a benchmark model for the role of DNA methylation in adult stem cells and in later lineage specification. Indeed, all myeloid and lymphoid blood lineages are differentiated from hematopoietic stem cells [29], which are achieved through the activity of a number of genes controlling cell fate tightly regulated by their DNA methylation status [30]. Conversely, aberrant DNA methylation profiles contribute to the occurrence of several human diseases, including cancer, autoimmune diseases, neurological defects, and metabolic disorders [31,32].

Methyl groups for DNA methylation originate from the universal methyl donor S-adenosylmethionine (SAM) [33]. SAM is synthesized in the methionine cycle by several precursors present in diet, including methionine, folate, choline, betaine and the B2, B6, and B12 vitamins. All of them enter the methionine cycle at different sites and contribute to SAM synthesis [34]. Deficiencies in these nutrients may result in changes in the SAM pool, which can also influence DNMT activity and DNA methylation. The establishment and maintenance of the Methylome is therefore vulnerable to nutritional factors. Indeed, nutritional challenges throughout a person's lifetime might have a major impact on DNA methylation, as well on development and the individual's health.

\section{Time Points of Plasticity in the Epigenetic System}

It is now well-established that different dietary regimens can alter epigenetic processes and may therefore contribute to increasing the susceptibility to metabolic disorders including obesity and T2D. A further question is at which time points during ontogenesis and subsequent life the epigenetic system is more sensitive to nutritional factors, which may ultimately have long-term effects on gene expression profiles.

Broad evidence suggests that, in mammals, early development (especially fetal development and/or early neonatal growth) is the most critical period for establishment of the genome-wide epigenetic profiles. Single mismatches at this time may result in disadvantageous changes causing embryonic lethality, developmental malformations, and an increased risk of disease, including metabolic disturbances [13]. At this critical stage in development, exceptionally rapid cell differentiation and complex epigenetic remodelling occur, making ontogenesis particularly vulnerable to nutritional insults, that can disrupt the correct make up of epigenetic marks that, once established, remain highly stable [35]. Hence, early development is a period of exceptional epigenome plasticity, and represents a time when nutritionally-induced epigenetic errors may have major consequences for the health.

However, it is also becoming clearer that nutritional effects on the epigenome may occur throughout the entire life time, especially during long-term dietary transitions [36]. Dietary transitions are prolonged periods of time (ranging from weeks to months in animal models to years in humans) during which individuals are exposed to diets characterized by malnutrition (both under- and over-nutrition). These situations may cause subtle and long-lasting changes in gene expression. Some of these changes 
are mediated by epigenetic mechanisms that, while potentially reversible, remain stable and may seriously affect phenotypes.

Hence, nutritional exposures occurring during all stages of the life time can have persistent consequences on health or disease risk. In this review, we will focus on and discuss intervention studies examining the impact of different diets on mammal DNA methylation and shaping the metabolic disease phenotype. The reported interventions include protein deficiency, fat overfeeding and caloric restriction (CR) (Figure 1). The first section is dedicated to the Agouti mouse model which serves as a key example of the association between diet and DNA methylation.

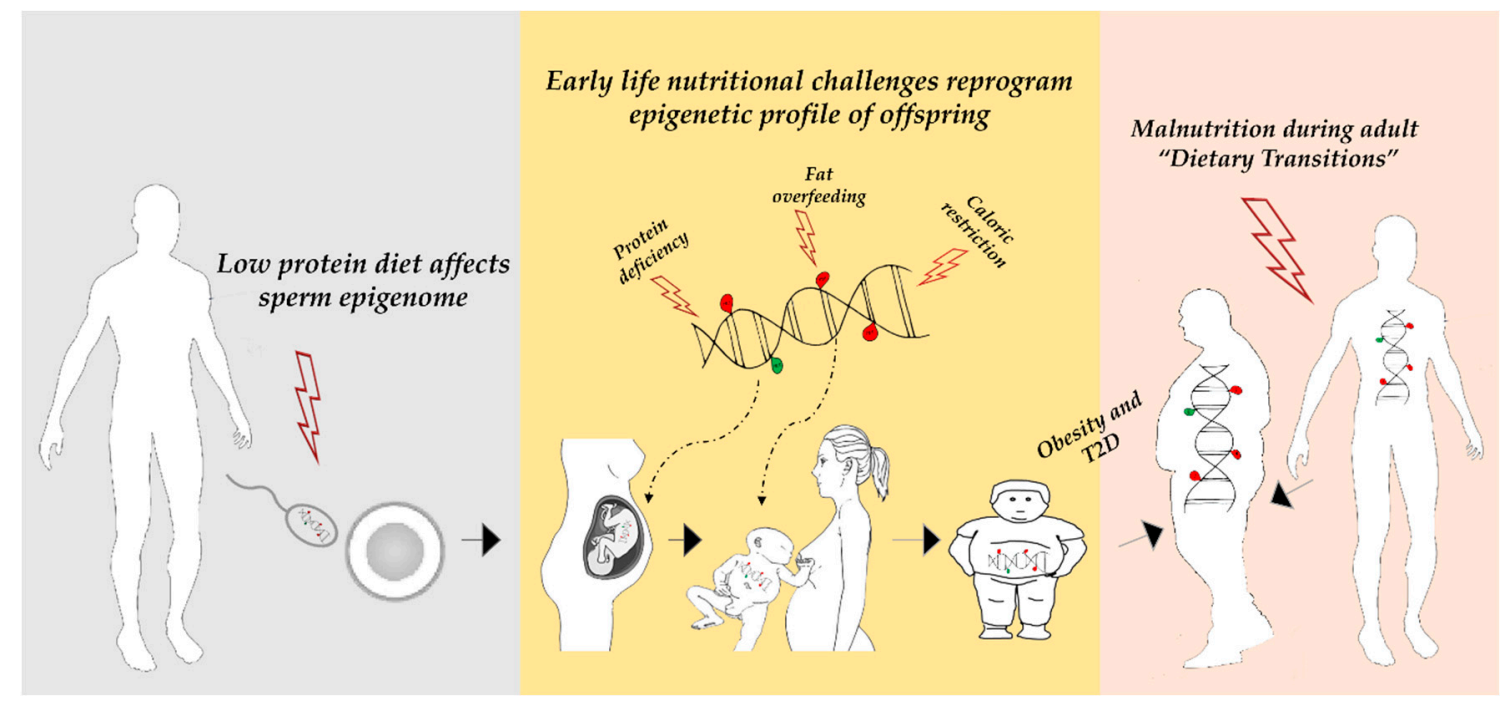

Figure 1. Altered nutritional exposures during the life time can induce persistent changes in DNA methylation, leading to an increased susceptibility to obesity and type 2 diabetes (T2D). Left: paternal low protein diet alters spermatozoa methylome. This may programme the epigenetics of the germ line which, in turn, may be inherited and influence offspring metabolic disturbance risk. Middle: early development is a period particularly vulnerable to nutritional challenges that can disrupt the correct make up of DNA methylation marks that, once established, remain highly stable. Right: exposure to a prolonged period of diet characterized by malnutrition throughout the life, may cause permanent epigenetically-associated changes in gene expression that can contribute to shape the disease phenotype.

\section{The Agouti Mouse Model}

Perhaps the most striking example of how DNA methylation changes induced by maternal diet during pregnancy can dramatically alter the phenotype in the offspring is offered by the agouti viable yellow (Avy) mouse [37]. The agouti-related neuropeptide (Agrp) gene encodes a paracrine factor that stimulates the production of a yellow pigment (pheomelanin) rather than the black pigment (eumelanin) in the follicles of the hair. The transcription of the gene from a wild-type allele is restricted to the hair follicles and results in the characteristic brown color of the wild-type mice. The Avy allele results from the transposition of a murine retrotransposon (intracisternal A particle, IAP) upstream of the agouti gene. The agouti gene expression in the other cells is regulated by the methylation of this IAP locus, that acts as a cryptic promoter. An aberrant expression of the agouti gene gives rise to the yellow fur, obesity, diabetes and tumorigenesis (the agouti disease phenotype).

Interestingly, $\mathrm{CpG}$ methylation in the Avy IAP inversely correlates with ectopic agouti expression. Thus, the isogenic offspring vary in agouti expression depending on the availability of the developmental methyl group. If a pregnant agouti mouse receives a dietary supplement that can release the methyl groups-such as folic acid, vitamin B12, or choline-the pups' agouti genes become methylated and thus inactive. These pups still carry the agouti gene but they lose the agouti disease phenotype: they have brown fur and no increased tendency to develop metabolic disorders and cancer. In addition, these effects are also inherited in the F2 generation suggesting a germline transmission of the epigenetic 
changes [38]. Thus, suboptimal early nutrition alters the establishment of the DNA methylation profiles in the fetus and has adverse metabolic effects on the offspring's health, clearly showing the direct link between diet, DNA methylation, and the increased risk of obesity and diabetes in adulthood.

\section{Nutritional Factors Affecting DNA Methylation}

\subsection{Protein Malnutrition}

A low-protein diet, frequently used as a model for maternal malnutrition, has been reported to induce changes in DNA methylation and metabolic disturbances that may persist into adulthood.

In rodent models, it has been shown that a maternal protein deficiency during pregnancy results in global DNA hypermethylation in the offspring livers. This methylation pattern has been associated with alterations in glucose tolerance and hypertension in adults [39]. A suboptimal protein intake during pregnancy may also induce locus-specific alterations in DNA methylation. These changes in DNA methylation correlated with altered gene expression (or function), and, importantly, remained stable until adulthood. The affected genes play a significant role in key metabolic processes, including liver lipid metabolism (glucocorticoid receptor $(G R)$ [40]; peroxisome proliferator-activated receptor alpha $(P P A R \alpha)$ [41]; liver $\mathrm{X}$ receptor alpha $(L x r \alpha)$ [42]), pancreatic $\beta$-cell function (hepatocyte nuclear-4-alpha $(H n f 4 \alpha)$ [43]), and appetite and energy balance regulation (orexigenic/anorexigenic genes neuropeptide $\mathrm{Y}$ and proopiomelanocortin C (Nyp) [44]; leptin (Lep) [45]). Taken together, these findings indicate that a maternal low protein diet persistently alters DNA methylation profiles and function of several genes important in metabolism. It is possible that some of these nutritionally-induced epigenetic alterations may explain, at least in part, the development of obesity, insulin resistance, and T2D in adults (Figure 1).

In addition, a paternal low protein diet also seems to induce changes of DNA methylation. Watkins et al. [46] have recently developed a mouse paternal low-protein diet (LPD) model to determine LPD impact on semen quality, maternal uterine physiology, and adult offspring health. They have demonstrated that paternal LPD induces sperm-DNA hypomethylation in conjunction with blunted female reproductive tract embryotrophic, immunological, and vascular remodeling responses. Interestingly, they relate the sperm- and seminal plasma-specific epigenetic programming effects of the paternal diet with an elevated offspring adiposity, metabolic dysfunction, and altered gut microbiota. Thus, nutritional deficiencies in paternal diet may also programme the epigenome of the germ line which, in turn, may be inherited and influence offspring metabolic disease risk (Figure 1).

\subsection{Global Caloric Restriction}

\subsubsection{Animal Models}

A moderate restriction of energy intake during early development is associated with epigenetic modifications that persist in the adult [47]. A maternal energy restriction alters DNA methylation in the insulin-like growth factor 2/H19 imprinted maternally expressed transcript (IGF2/H19) gene. An aberrant DNA methylation at IGF2/H19 locus at birth increases the risk of excessive weight and obesity in children [48]. In addition, $C R$ in pregnant baboons has been shown to increase the expression of the gluconeogenic enzyme PCK1 in the fetal liver, along with PCK1 promoter hypomethylation [49]. These alterations were suggested to have negative effects on fetal metabolism and cause metabolic dysfunction later in life.

\subsubsection{Human Studies}

In humans, the first well-documented evidence of nutrition impact on the individual epigenetic profile comes from investigation on women who were prenatally exposed to famine during the Dutch Hunger Winter. In an elegant study, Heijmans and colleagues [50] demonstrated that the insulin-like growth factor 2 (IGF2) locus was less methylated in the white blood cells of individuals who had 
been prenatally exposed to famine when compared to matched controls. Subsequent investigations have described altered DNA methylation in other genes in the famine exposed-group, including INSIGF2 (INS-IGF2 Readthrough), GNASAS1 (GNAS antisense RNA 1), MEG3 (Maternally expressed 3), IL-10 (Interleukin-10), and LEP, some of which have a known role in metabolic disorders [51]. These findings have initially substantiated the concept that a differential DNA methylation at these genes links early nutrition to adult metabolic disease. Interestingly, the association reported in these studies was specific for periconceptional exposure, reinforcing the hypothesis that early-life environmental conditions can cause epigenetic changes in humans that persist throughout the adult life (Figure 1).

Caloric restriction has attracted considerable attention due to its effects on health. It has been shown to be capable of extending the lifespan and delaying the onset of chronic diseases, including obesity and T2D [52] (Figure 1). Caloric restriction may exert its beneficial effects through epigenetic mechanisms as well. Short-term calorie restriction on obese subjects may revert the aberrant DNA methylation at specific loci, including Wilms tumor 1 (WT1) and Tumor necrosis factor-alpha (TNF- $\alpha$ ) [53,54]. In adult humans, Bouchard et al. [55] reported a different methylation profile and transcriptomic difference in the adipose tissue in high compared to low responders to caloric restriction. The genes identified in these studies were associated to body weight control and insulin secretion. Fasting periods can also influence health and disease through DNA methylation. For example, individuals with low birth weight (LBW) have an increased risk of insulin resistance and T2D in adult life, and they respond differently to prolonged fasting than individuals with normal birth weight (NBW). The differential response to fasting was associated with increased DNA methylation at PPARGC1A in the muscle of subjects with a LBW [56]. More recently, Line Hjort et al. [57] analysed the effects of a 36-hour fast on DNA methylation and expression of the adiponectin (ADIPOQ) and leptin (LEP) genes in the subcutaneous fat from the same subjects previously studied by the authors of [56]. The LEP and $A D I P O Q$ DNA methylation levels increased with 36-hour fasting in NBW subjects only. In contrast, the ADIPOQ mRNA levels increased in LBW males, whereas the LEP expression did not change with fasting. This differential response to fasting led the authors to propose that LBW subjects may be more inflexible in altering their DNA methylation status when metabolically challenged, and therefore are at greater risk of metabolic disturbance.

\subsection{High-Fat Feeding}

High-fat feeding may also induce DNA methylation changes at key metabolic genes that could influence their expression and predisposing to metabolic dysfunctions [58].

\subsubsection{Animal Models}

In the context of early life nutrition, maternal high-fat feeding during pregnancy affects DNA methylation and the expression of genes related to dopamine and opioid systems in the brain of the offspring [59]. This seems to increase behavioral preferences for palatable foods, thereby contributing to the risk of a metabolic disorders.

The lactation-suckling period in mice causes epigenetic changes that influence risk of developing obesity later in life. Milk lipids have been shown to activate the PPAR $\alpha$ gene [60], a key regulator of the hepatic liver metabolism. By using a whole-genome DNA methylation analysis, Yuan et al. [61] identified few PPAR $\alpha$ target genes, including fibroblast growth factor-21 ( $F g f 21$ ), that undergo ligand-activated PPAR $\alpha$-dependent DNA demethylation during the perinatal period. $F g f 21$ is an endocrine factor that regulates glucose uptake, metabolism, and energy expenditure [62]. Interestingly, once established in early life, the DNA methylation levels at F $g$ f21 remain stable in adulthood. Low levels of $F g f 21$ methylation correlates with protection from diet-induced obesity in older animals. These same authors further demonstrated that in newborn mice lactation keeps F $g$ f21 methylation to low levels. In a further recent study, Butruille et al. [63] showed that maternal high-fat feeding during lactation induced qualitative changes in breast milk fatty acid (FA) composition (high n-6/n-3 
polyunsaturated FA ratio and low medium-chain FA content). As a consequence, the offspring of adults fed HFD were predisposed to weight gain and showed increased visceral adipose tissue growth. Remarkably, these events were associated with an altered DNA methylation profile of the stearoyl-CoA desaturase-1 (SCD1), a key enzyme of the fatty acid metabolism. These findings suggest a link between breastfeeding and the susceptibility for weight gain and adiposity, and elegantly describe how specific DNA methylation marks established early in life have long-lasting effects (Figure 1).

In adult rodents, HFD has been reported to induce DNA methylation changes in the white adipose tissue (WAT) at loci close to genes controlling metabolism [64]. Our own studies have shown that 5-month HFD feeding alters promoter methylation and expression of the Ankrd26 gene [65]. In mice, this gene is highly expressed in both the hypothalamus and WAT and its partial inactivation induces marked hyperphagia, severe obesity and diabetes in vivo, while in humans ANKRD26 has been associated to certain forms of hereditary obesity [4]. More recently we have also shown that ANKRD26 mRNA levels are negatively correlated with body mass index (BMI) in humans. In addition, we have further uncovered that HFD treatment produced adipose tissue abnormalities accompanied by epigenetic changes at the Hoxa5 adipose tissue remodeling gene [15]. The Hoxa5 gene was highly methylated at its 5'UTR and transcriptionally repressed in the WAT from HFD-induced obese mice. Interestingly, when obese mice exposed to the chronic HFD intervention were returned to standard chow diet (STD) for a further two-month period, the Hoxa5 DNA methylation and expression levels returned to values similar to those of mice maintained under a STD since the inception of the study. These findings not only emphasize the dynamic nature of DNA methylation but also strongly suggests that Hoxa5 may represent a potential tool to quantify the obesity response to nutritional intervention. The most relevant findings of the above-mentioned studies are reported in Table 1.

Table 1. List of relevant nutrition-sensitive DNA methylation loci in humans and model organisms.

\begin{tabular}{|c|c|c|c|c|}
\hline Dietary Condition & DNA Methylation Regulated Locus(i) & Sample Type(s) & Species & References \\
\hline \multirow[t]{2}{*}{ Low protein diet } & GR, PPAR $\alpha$, Hnf4a, Nyp, Pomc & $\begin{array}{l}\text { Liver, pancreatic islets, } \\
\text { hypothalamus }\end{array}$ & Rat & {$[40,41,43,44]$} \\
\hline & Lxr $\alpha$, Lep & Liver, adipose tissue & Mouse & {$[42,45]$} \\
\hline \multirow{6}{*}{ Caloric restriction } & $I G F 2 / H 19$ & Adrenal gland & Sheep & [47] \\
\hline & PCK 1 & Fetal liver & Baboon & [49] \\
\hline & IGF2, INSIGF2, GNASAS1, MEG3, IL-10, & Blood & Human & {$[50,51]$} \\
\hline & $W T 1, T N F-\alpha$ & Blood & Human & {$[53,54]$} \\
\hline & PPARGC1A & Skeletal muscle & Human & {$[56]$} \\
\hline & $A D I P O Q, L E P$ & Adipose tissue & Human & {$[57]$} \\
\hline \multirow{3}{*}{ High-fat feeding } & $F g f 21$ & Liver & Mouse & [61] \\
\hline & Scd1 & Adipose tissue & Rat & {$[63]$} \\
\hline & Ankrd26, Hoxa5 & Adipose tissue & Mouse & {$[15,65]$} \\
\hline
\end{tabular}

\subsubsection{Human Studies}

Only a few studies have been carried out assessing the relationship between overfeeding and changes in DNA methylation in humans (Table 2). A five-day overfeeding intervention resulted in alterations of both gene expression and methylation patterns in human adipose tissue and skeletal muscle $[11,66,67]$. Interestingly, these changes were not fully reversed by low-caloric diet, even after 6-8 weeks, suggesting that changes in methylation at certain loci may accumulate over time. In another study, PPARGC1A promoter methylation in the skeletal muscle increased after five days of overfeeding [68]. In this case, however, the methylation levels were reversed after the introduction of the low caloric diet. 
Table 2. Effects of a 5-day high-fat overfeeding diet on DNA methylation in humans.

\begin{tabular}{|c|c|c|c|c|}
\hline Study Population & Sample Type & $\begin{array}{c}\text { Methylation } \\
\text { Strategy }\end{array}$ & Epigenetically Regulated Genes & Reference \\
\hline Healthy men $(n=21)$ & Skeletal muscle & Genome-wide * & $\begin{array}{c}\text { DNM2, MGMT, SLC2A3/GLUT3, MRC1, } \\
\text { ACAT2, APOH, DCC, ESRRG, FOLH1, } \\
\text { GTF2I, MC4R, MYST4, AKT2, } \\
\text { PDX1/IPF1, SLC3OA8, CDKN2A, } \\
\text { CDKN2B, PPARG }\end{array}$ & [67] \\
\hline $\begin{array}{l}\text { NBW }(n=23) \\
\text { LBW }(n=17)\end{array}$ & Skeletal muscle & Genome-wide * & $\begin{array}{c}\text { IGF2R, TNF, CDKN2B, KCNJ11, KCNQ1, } \\
\text { GABRA3, UGT2B7, FOLH1, FUT1, } \\
\text { NDUFS2, FAP }\end{array}$ & [11] \\
\hline $\begin{array}{l}\text { NBW }(n=24) \\
\text { LBW }(n=16)\end{array}$ & $\begin{array}{l}\text { Subcutaneous } \\
\text { adipose tissue }\end{array}$ & Genome-wide * & $\begin{array}{c}\text { ACAT1, CPLX1, FADS2, GPRC5B, } \\
\text { HCCA2, IGF2R, CIDEA, KLF14, } \\
\text { PRDM16 }\end{array}$ & [66] \\
\hline $\begin{array}{l}\text { NBW }(n=26), \\
\text { LBW }(n=20)\end{array}$ & Skeletal muscle & Gene-specific & PPARGC1A & [68] \\
\hline
\end{tabular}

Recent findings have suggested that not only the amount but also the composition of dietary fat may have profound effects on the risk of contracting a metabolic disease such as obesity, insulin resistance or T2D [69]. A randomized control study examined the impact of a 7-week diet of either excessive saturated or polyunsaturated fats on the global DNA methylation pattern in human adipose tissue. Both diets resulted in a similar weight gain and increased methylation in the adipose tissue. However, the DNA methylation of individual genes and CpG sites was differently regulated by the saturated and polyunsaturated fatty acid administration. Genes that were involved in the carbohydrate metabolism, lipid metabolism, and oxidative phosphorylation were among the most significantly affected by these interventions (Table 3) [70]. Finally, in vitro exposure to palmitate of human pancreatic islets resulted in global DNA hyper-methylation along with changes in the expression of several genes which may contribute to impaired insulin secretion observed in these studies [71].

Table 3. Impact of 7 weeks of overfeeding with SFAs or PUFAs on DNA methylation in humans.

\begin{tabular}{|c|c|c|c|c|}
\hline Study Population & $\begin{array}{l}\text { Sample } \\
\text { Type }\end{array}$ & $\begin{array}{c}\text { Methylation } \\
\text { Strategy }\end{array}$ & Epigenetically Regulated Genes & Reference \\
\hline $\begin{array}{l}\text { LIPOGAIN cohort }(n=31 ; \\
\text { SFA group } n=17 ; \\
\text { PUFA group } n=14)\end{array}$ & $\begin{array}{l}\text { Subcutaneous } \\
\text { adipose } \\
\text { tissue }\end{array}$ & Genome-wide* & $\begin{array}{c}\text { RPSAP9, ADIPOQ, FABP1, FABP2, } \\
\text { FABP7, MC2R, XKR4, MC3R, MC5R, } \\
\text { PPARGC1A, TNF, ACO1, SLC37A2, AR, } \\
\text { CXCL2, FOXO1, FTO, IL6, INSR, MC1R, } \\
\text { MC3R, MEF2A, NEGR1, POMC }\end{array}$ & [70] \\
\hline
\end{tabular}

SFAs, saturated fatty acids; PUFA, polyunsaturated fatty acids. * Top scored affected genes are presented.

\section{DNA Methylation and Future Medicine}

As described in this review, DNA methylation changes in key metabolic tissues may contribute to the pathogenesis of obesity and T2D. This has attracted interest in the identification of epigenetic biomarkers that, in the future, may prove effective in the prediction of metabolic disorders. To achieve this objective, most studies concentrated on blood cells because of their accessibility and diagnostic accuracy [72]. Importantly, obesity- and T2D-associated DNA methylation changes in metabolically active tissues (pancreatic $\beta$-cells, adipose tissue, liver and muscle) have been reported to be quite often reflected in the blood-borne cells, suggesting that blood samples might be used as a surrogate of major metabolic organs [72]. The prognostic significance of similar DNA-based epigenetic biomarkers has already been demonstrated in cancer patients [73].

A number of studies have investigated the potential of using DNA methylation markers to identify subjects at increased risk and to predict the incidence of metabolic diseases in different prospective 
cohorts [74]. Godfrey et al. [75] reported that epigenetic analysis at the perinatal stage may be used to predict adiposity occurring in childhood. In particular, the methylation of the RXRA (Retinoid X receptor alpha) promoter at specific sites in the umbilical cord tissue DNA correlated with the level of adiposity at six and nine years of age. RXRA controls the adipose tissue metabolism and insulin sensitivity. Similarly, a low DNA methylation level at the FTO (FTO alpha-ketoglutarate dependent dioxygenase) gene represents an early marker of T2D. FTO is a well-known risk gene for obesity and T2D [76]. Its effect on the disease phenotype has been recently reported to be functionally connected with the regulation of the IRX3 (Iroquois homeobox 3) gene, an important determinant of body mass and composition [77]. Importantly, the predictive power of RXRA and FTO methylation are significantly greater than that of any genetic variants so far described. This further suggests that epigenetic analysis at the perinatal stage may identify the risk of metabolic alterations with unprecedented power and accuracy. More recently, other studies have shown a suggestive link between DNA methylation and adiposity. Sharp et al. [78] reported that the offspring of obese mothers displayed a number of CpG sites differently methylated in the cord blood when compared with the offspring from lean mothers. In this regard, epigenetic dysregulation of several genes (Nnat and Peg3) of the Trim28-imprinted gene network also influences the risk for the offspring of developing obesity, as elegantly described by Dalgaard et al. [79]. Additionally, the DNA methylation signature in blood cells is distinct between early-onset obese and control individuals [80]. Moreover, Dick et al. [81] described an association between an increased BMI and an increased methylation at the HIF3A locus in blood cells and in adipose tissue of the same subjects, suggesting that DNA methylation perturbation of hypoxia-inducible factor (HIF) signaling might represent a mark of increased body adiposity.

Several studies have shown that disturbances in DNA methylation may predict future development of T2D. Chambers et al. [82] analyzed T2D-associated DNA methylation changes in blood samples from 2664 Indian Asians and replicated the study findings in 1141 Europeans. These authors uncovered that altered methylation at the ABCG1 (ATP binding cassette subfamily G member 1), PHOSPHO1 (Phosphoethanolamine/phosphocholine phosphatase), SOCS3 (Suppressor of cytokine signaling 3), SREBF1 (Sterol regulatory element binding transcription factor 1), and TXNIP (Thioredoxin interacting protein) loci was strongly associated with future development of T2D. Remarkably, the combined methylation scores of these loci predicts future risk of T2D, independently of traditional T2D risk factors, including family history of T2D, BMI, physical activity, and hemoglobin A1c (HbA1c). These methylation marks were further analyzed in the Botnia prospective cohort where only the association between $A B C G 1$ and PHOSPHO1 methylation and future T2D risk was confirmed [83]. These authors found that methylation at the $A B C G 1$ locus associated with increased risk, whereas methylation at $P H O S P H O 1$ associated with a decreased risk of future T2D. These changes could be replicated in the blood samples of diabetic twins compared to their non-diabetic counterparts [83]. The association between $A B C G 1$ locus methylation and T2D incidence has recently been reported in independent studies [84,85]. ABCG1 plays a major role in cholesterol and phospholipid transport [86]. Cholesterol abnormalities are hallmark of T2D. This may suggest that an altered DNA methylation at the $A B C G 1$ locus may also influence circulating cholesterol levels, and thus have an impact on the onset and progression of T2D and other metabolic disturbances. Aging is associated with an increased T2D risk. In this context, Bacos et al. [87] demonstrated that blood-borne epigenetic marks reflect age-related DNA methylation changes in human islets, and that altered methylation at certain genes are associated with the future insulin-secreting capacity and future risk of T2D. Finally, in an epigenome-wide association study (EWAS), Wahl et al. [88] identified, in whole blood samples from $\sim 10,000$ individuals, 187 CpG sites significantly associated with obesity. Interestingly, DNA methylation changes at these sites predicted the future risk of T2D.

DNA methylation may be used as a marker to predict the response to treatment as well. Successful intervention in diseased individuals state are indeed expected to change methylation levels. For instance, in the intervention study published by Cordero et al. [89], 27 obese women were prescribed an 8-week low-calorie diet. At the end of the dietary treatment, 21 subjects presented a positive response to the diet 
( $>5 \%$ weight loss) whereas the others were considered non-responders ( $<5 \%$ weight loss). Interestingly, the responders had lower DNA methylation levels in the promoter of the LEP and TNF-alpha genes than non-responders at baseline. These findings suggest that methylation levels at these loci could be used to predict the susceptibility to weight loss by nutritional intervention. In addition, those subjects who successfully maintained weight loss for three years from inception of diet have DNA methylation levels that are similar to normal-weight individuals but different from their obese counterparts [90]. A nutritional educational weight loss program in overweight and obese adolescents also revealed that the methylation status of genes related to glucose metabolism, insulin resistance, and inflammation was associated to weight control and glucose as well as lipid metabolism [91]. A physical activity program further identified strong associations between the methylation profile at a number of CpG sites and weight loss in blood samples from 20 healthy women [92]. Finally, Perfilyev et al. [70] found a significant association between DNA methylation in adipose tissue at baseline and weight increase in response to excess energy intake.

As previously mentioned, a further promising aspect of epigenetic changes lies in their dynamic nature and potential reversibility under targeted interventions. This ambitious task might be accomplished by normalizing/optimizing modifiable and lifestyle-sensitive epigenetic factors (e.g., nutritional factors, physical activity) or by using epigenetic modulating agents. Several epigenetic modifier agents have so far been identified, including DNMT inhibitors (e.g., azacytidine) and histone deacetylase inhibitors (HDACi) (e.g., valproic acid (VPA) and trichostatin A (TSA)). Medications targeting epigenetic mechanisms have been used in oncology for a long time [93]. Epigenetic drugs may also have beneficial effects on T2D and obesity risk. There is mounting evidence showing that HDACs regulate glucose homeostasis and islet function [94]. For instance, MC1568, an HDACi, improves insulin secretion in pancreatic islets from human donors with T2D [95]. MC1568 inhibits HDAC7, the overexpression of which in clonal $B$ cells and rat islets results in impaired glucose-stimulated insulin secretion and mitochondrial dysfunction [96]. One of the epi-drugs tested for T2D is valproic acid, but the results from these studies have been inconclusive thus far [97,98]. Recently, Bridgeman et al. [99] reviewed the epigenetic effects of metformin. This well-known antidiabetic agent modulates the activity of numerous epigenetic modifying enzymes, such as HDACi, histone acetyltransferases (HATs), and DNMTs, influencing thus the epigenome and gene expression. It has been argued that these effects may contribute to the antidiabetic properties of metformin. Despite a significant degree of uncertainty existing in relation to the overall effect of metformin on the epigenome, this medication holds great promise in targeting the epigenome to treat $\mathrm{T} 2 \mathrm{D}$ and other metabolic disturbances.

There are also concerns related to the use of epigenetic drugs in metabolic dysfunction. First, the low specificity and global action of these agents may cause adverse effects. Secondly, the number of epigenetic changes that must be reverted is uncertain. In cancer, the DNA methylation of larger genomic areas is robustly modified, and the differences between normal and malignant cells are more evident, so that epigenetic drugs can be used in relatively high doses [100]. In metabolic diseases, the differences in DNA methylation between affected and non-affected individuals are more modest (about $10-20 \%$ at most), and mainly locus/i-specific [101]. Therefore, the development of molecules/substances with a more selective modulatory action on epigenetic processes should represent a real challenge to develop therapeutic strategies in the future. The search for nutrients and compounds found in food that are able to slightly modify the epigenome in key organs related to obesity and T2D holds great promises for obtaining functional foods that can help in preventing or combating metabolic diseases.

\section{Conclusions}

The onset of obesity and T2D seems to be due to the interplay between post-natal and fetal environment and inherited genetic factors that determine the individual's susceptibility to developing the disease phenotype. However, growing evidence suggests that one of the links between the environmental factors and the higher predisposition to developing obesity and T2D is DNA methylation. The studies outlined above establish that, to a significant extent, nutritional factors act by modulating 
DNA methylation, and that some of these factors might be used in obesity and T2D therapy due, at least in part, to their modulatory action on epigenetic mechanisms. Importantly, nutritional challenges from the prenatal stage to adulthood can lead to alterations in DNA methylation that influence the risk of developing obesity and T2D.

The blood-cell DNA methylation signatures in T2D and obesity have been tested and hold promise as surrogate markers for metabolic diseases. These findings will have important implications for the development of non-invasive tests, given the difficulty in accessing key tissues for obesity and T2D, particularly for longitudinal studies. Profiling DNA methylation in blood could be used to monitor high-risk individuals, delay or prevent the onset of T2D and obesity, and facilitate early intervention strategies. Most importantly, the dynamic and reversible nature of epigenetic mechanisms offers unique opportunities for the development of strategies for the treatment and prevention of obesity and T2D. Nonetheless, the pathway towards translating basic research into clinical application is still challenging.

Author Contributions: C.M., F.B. and G.A.R. conceived the idea and edited the manuscript. L.P., R.S., A.N., M.L., and P.M. wrote the paper. L.P. and M.L. prepared the figures and tables. All authors reviewed the manuscript.

Acknowledgments: This study was supported by the Ministero dell'Istruzione, dell'Università e della Ricerca Scientifica (grants PRIN 2015 and PRIN 2017), by the Regione Campania POR FESR 2014-2020 (Obiettivo specifico 1.2.) Manifestazione di Interesse per la Realizzazione di Technology Platform nell'ambito della Lotta alle Patologie Oncologiche" Projects: RARE PLAT NET, SATIN, and COEPICA, by the Associazione Italiana per la Ricerca sul Cancro (AIRC, grant IG19001), and by the INCIPIT program co-funded by the European Union's Horizon 2020 Programme (Marie Skłodowska-Curie Actions, Grant No 665403).

Conflicts of Interest: The authors declare no conflict of interest.

\section{Abbreviations}

$\begin{array}{ll}\text { T2D } & \text { Type 2 diabetes } \\ \text { GWAS } & \text { Genome-wide association studies } \\ \text { HFD } & \text { High-fat diet } \\ \text { DNMT } & \text { DNA methyltransferase } \\ \text { C } p \text { G } & \text { Cytidine-phosphate-Guanine } \\ \text { 5mC } & \text { 5-methyl cytosine } \\ \text { TET } & \text { Ten-eleven translocation } \\ \text { SAM } & \text { S--adenosyl-methionine } \\ \text { CR } & \text { Caloric restriction } \\ \text { Avy } & \text { Agouti viable yellow } \\ \text { Agrp } & \text { Agouti related neuropeptide } \\ \text { IAP } & \text { Intracisternal A particle } \\ \text { GR } & \text { Glucocorticoid receptor } \\ \text { PPAR } \alpha & \text { Peroxisome proliferator-activated receptor alpha } \\ \text { Lxr } \alpha & \text { Liver X receptor alpha } \\ \text { Hnf4 } \alpha & \text { Hepatocyte nuclear factor 4 alpha } \\ \text { Nyp } & \text { Neuropeptide Y } \\ \text { Pomc } & \text { Pro-opiomelanocortin } \\ \text { LEP } & \text { Leptin } \\ \text { LPD } & \text { Low-protein diet } \\ \text { IGF2/H19 } & \text { Insulin like growth factor 2/ H19 imprinted maternally expressed transcript } \\ \text { PCK1 } & \text { phosphoenolpyruvate carboxykinase 1 } \\ \text { INSIGF2 } & \text { INS-IGF2 Readthrough } \\ \text { GNASAS1 } & \text { GNAS antisense RNA 1 } \\ \text { MEG3 } & \text { Maternally expressed 3 } \\ \text { IL-10 } & \text { Interleukin-10 } \\ \text { WT1 } & \text { Wilms tumor 1 } \\ \text { TNF- } \alpha & \text { Tumor necrosis factor alpha } \\ & \end{array}$




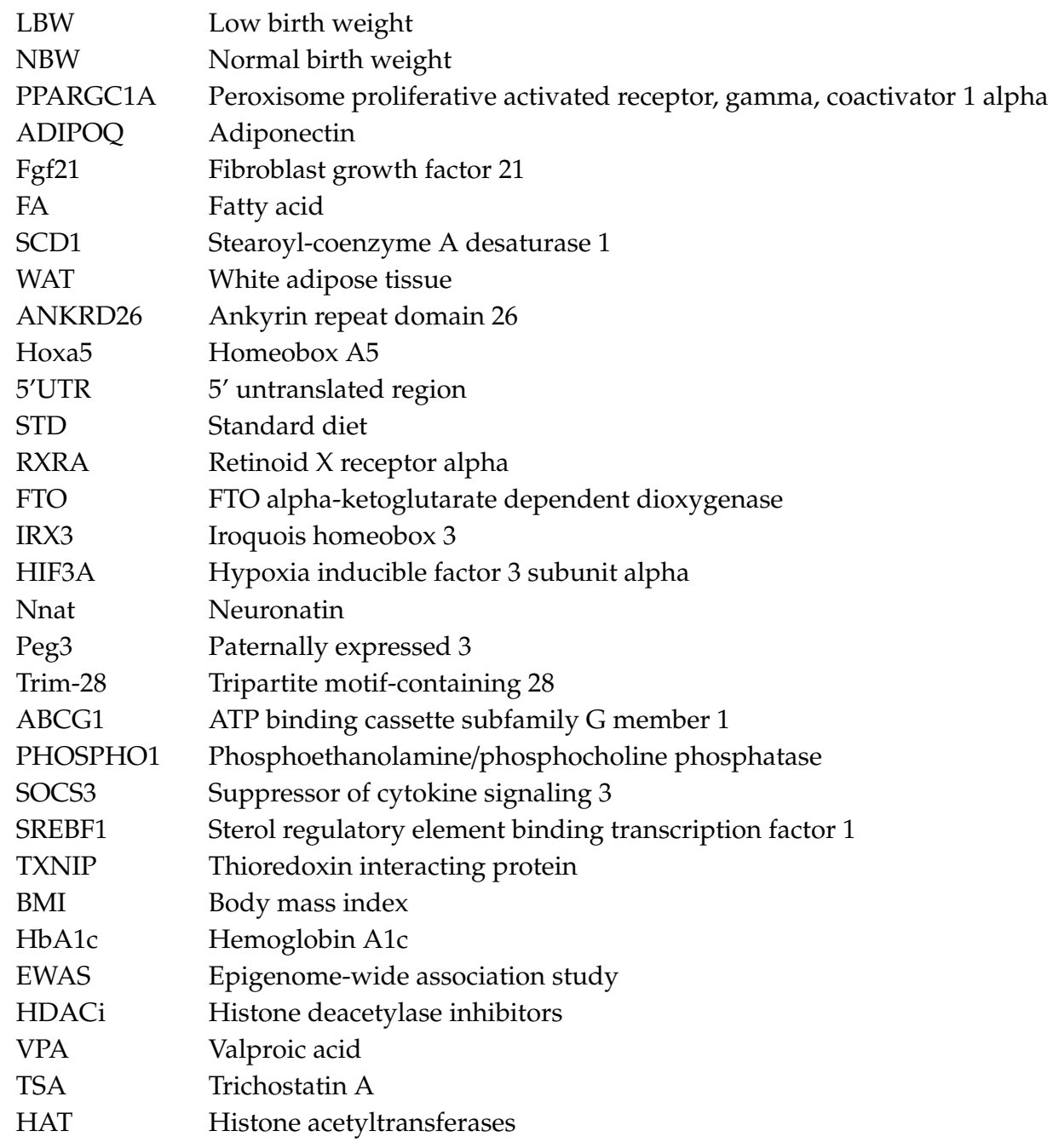

\section{References}

1. Locke, A.E.; Kahali, B.; Berndt, S.I.; Justice, A.E.; Pers, T.H.; Day, F.R.; Powell, C.; Vedantam, S.; Buchkovich, M.L.; Yang, J.; et al. Genetic studies of body mass index yield new insights for obesity biology. Nature 2015, 518, 197-206. [CrossRef] [PubMed]

2. Raciti, G.A.; Longo, M.; Parrillo, L.; Ciccarelli, M.; Mirra, P.; Ungaro, P.; Formisano, P.; Miele, C.; Béguinot, F. Understanding type 2 diabetes: From genetics to epigenetics. Acta Diabetol. 2015, 52, 821-827. [CrossRef] [PubMed]

3. Cheng, Z.; Zheng, L.; Almeida, F.A. Epigenetic reprogramming in metabolic disorders: Nutritional factors and beyond. J. Nutr. Biochem. 2018, 54, 1-10. [CrossRef] [PubMed]

4. Desiderio, A.; Spinelli, R.; Ciccarelli, M.; Nigro, C.; Miele, C.; Beguinot, F.; Raciti, G.A. Epigenetics: Spotlight on type 2 diabetes and obesity. J. Endocrinol. Invest. 2016, 39, 1095-1103. [CrossRef] [PubMed]

5. Multhaup, M.L.; Seldin, M.M.; Jaffe, A.E.; Lei, X.; Kirchner, H.; Mondal, P.; Li, Y.; Rodriguez, V.; Drong, A.; Hussain, M.; et al. Mouse-human experimental epigenetic analysis unmasks dietary targets and genetic liability for diabetic phenotypes. Cell Metab. 2015, 21, 138-149. [CrossRef] [PubMed]

6. Szabó, M.; Máte, B.; Csép, K.; Benedek, T. Epigenetic modification linked to T2D, the heritability gap, and potential targets. Biochem. Genet. 2018, 56, 553-574. [CrossRef] [PubMed]

7. Cheng, Z.; Almeida, F.A. Mitochondrial alteration in type 2 diabetes and obesity: An epigenetic link. Cell Cycle 2014, 13, 890-897. [CrossRef]

8. Van Dijk, S.J.; Tellam, R.L.; Morrison, J.L.; Muhlhausler, B.S.; Molloy, P.L. Recent developments on the role of epigenetics in obesity and metabolic disease. Clin. Epigenetics 2015, 7, 66. [CrossRef] 
9. Leung, A.; Parks, B.W.; Du, J.; Trac, C.; Setten, R.; Chen, Y.; Brown, K.; Lusis, A.J.; Natarajan, R.; Schones, D.E. Open chromatin profiling in mice livers reveals unique chromatin variations induced by high fat diet. J. Biol. Chem. 2014, 289, 23557-23567. [CrossRef]

10. De Castro Barbosa, T.; Ingerslev, L.R.; Alm, P.S.; Versteyhe, S.; Massart, J.; Rasmussen, M.; Donkin, I.; Sjögren, R.; Mudry, J.M.; Vetterli, L.; et al. High-fat diet reprograms the epigenome of rat spermatozoa and transgenerationally affects metabolism of the offspring. Mol. Metab. 2015, 5, 184-197. [CrossRef]

11. Jacobsen, S.C.; Gillberg, L.; Bork-Jensen, J.; Ribel-Madsen, R.; Lara, E.; Calvanese, V.; Ling, C.; Fernandez, A.F.; Fraga, M.F.; Poulsen, P.; et al. Young men with low birthweight exhibit decreased plasticity of genome-wide muscle DNA methylation by high-fat overfeeding. Diabetologia 2014, 57, 1154-1158. [CrossRef] [PubMed]

12. Vickers, M.H. Early life nutrition, epigenetics and programming of later life disease. Nutrients 2014, 6, 2165-2178. [CrossRef] [PubMed]

13. Li, Y. Epigenetic mechanism link maternal diets and gut microbiome to obesity in the offspring. Front Genet. 2018, 9, 342. [CrossRef] [PubMed]

14. Zhang, Y.; Kutateladze, T.G. Diet and the epigenome. Nat. Commun. 2018, 9, 3375. [CrossRef] [PubMed]

15. Parrillo, L.; Costa, V.; Raciti, G.A.; Longo, M.; Spinelli, R.; Esposito, R.; Nigro, C.; Vastolo, V.; Desiderio, A.; Zatterale, F.; et al. Hoxa5 undergoes dynamic DNA methylation and transcriptional repression in the adipose tissue of mice exposed to high-fat diet. Int J. Obes. 2016, 40, 929-937. [CrossRef] [PubMed]

16. Raciti, G.A.; Nigro, C.; Longo, M.; Parrillo, L.; Miele, C.; Formisano, P.; Béguinot, F. Personalized medicine and type 2 diabetes: Lesson from epigenetics. Epigenomics 2014, 6, 229-238. [CrossRef] [PubMed]

17. Xiao, F.H.; Wang, H.T.; Kong, Q.P. Dynamic DNA methylation during aging: A "prophet" of age-related outcomes. Front Genet. 2019, 10, 107. [CrossRef] [PubMed]

18. Jeltsch, A.; Jurkowska, R.Z. New concepts in DNA methylation. Trends Biochem. Sci. 2014, 39, 310-318. [CrossRef] [PubMed]

19. Jones, P.A. Functions of DNA methylation: Islands, start sites, gene bodies and beyond. Nat. Rev. Genet. 2012, 13, 484-492. [CrossRef]

20. Jang, H.S.; Shin, W.J.; Lee, J.E.; Do, J.T. CpG and non-CpG methylation in epigenetic gene regulation and brain function. Genes 2017, 8, 148. [CrossRef]

21. Longo, M.; Raciti, G.A.; Zatterale, F.; Parrillo, L.; Desiderio, A.; Spinelli, R.; Hammarstedt, A.; Hedjazifar, S.; Hoffmann, J.M.; Nigro, C.; et al. Epigenetic modifications of the Zfp/ZNF423 gene control murine adipogenic commitment and are dysregulated in human hypertrophic obesity. Diabetologia 2018, 61, 369-380. [CrossRef] [PubMed]

22. Fuks, F.; Hurd, P.J.; Wolf, D.; Nan, X.; Bird, A.P.; Kouzarides, T. The methyl-CpG-binding protein MeCP2 links DNA methylation to histone methylation. J. Biol. Chem. 2003, 278, 4035-4040. [CrossRef] [PubMed]

23. Yang, X.; Han, H.; De Carvalho, D.D.; Lay, F.D.; Jones, P.A.; Liang, G. Gene body methylation can alter gene expression and is a therapeutic target in cancer. Cancer Cell 2014, 26, 577-590. [CrossRef] [PubMed]

24. Chen, Z.X.; Riggs, A.D. DNA methylation and demethylation in mammals. J. Biol. Chem. 2011, 286, 18347-18353. [CrossRef] [PubMed]

25. Wolffe, A.P.; Jones, P.L.; Wade, P.A. DNA demethylation. Proc. Natl. Acad. Sci. USA 1999, 96, 5894-5896. [CrossRef] [PubMed]

26. Jin, C.; Lu, Y.; Jelinek, J.; Liang, S.; Estecio, M.R.; Barton, M.C.; Issa, J.P. TET1 is a maintenance DNA demethylase that prevents methylation spreading in differentiated cells. Nucleic Acids Res. 2014, 42, 6956-6971. [CrossRef]

27. Ichiyama, K.; Chen, T.; Wang, X.; Yan, X.; Kim, B.S.; Tanaka, S.; Ndiaye-Lobry, D.; Deng, Y.; Zou, Y.; Zheng, P.; et al. The methylcytosine dioxygenase Tet2 promotes DNA demethylation and activation of cytokine gene expression in T cells. Immunity 2015, 42, 613-626. [CrossRef]

28. Robertson, K.D. DNA methylation and human disease. Nat. Rev. Genet. 2005, 6, 597-610. [CrossRef]

29. Chao, M.P.; Seita, J.; Weissman, I.L. Establishment of a normal hematopoietic and leukemia stem cell hierarchy. Cold Spring Harb. Symp. Quant. Biol. 2008, 73, 439-449. [CrossRef]

30. Farlik, M.; Halbritter, F.; Müller, F.; Choudry, F.A.; Ebert, P.; Klughammer, J.; Farrow, S.; Santoro, A.; Ciaurro, V.; Mathur, A.; et al. DNA methylation dynamics of human hematopoietic stem cell differentiation. Cell Stem Cell 2016, 19, 808-822. [CrossRef] 
31. Côté, S.; Gagné-Ouellet, V.; Guay, S.P.; Allard, C.; Houde, A.A.; Perron, P.; Baillargeon, J.P.; Gaudet, D.; Guérin, R.; Brisson, D.; et al. PPARGC1 $\alpha$ gene DNA methylation variations in human placenta mediate the link between maternal hyperglycemia and leptin levels in newborns. Clin. Epigenetics 2016, 8, 72. [CrossRef] [PubMed]

32. Andrews, S.V.; Sheppard, B.; Windham, G.C.; Schieve, L.A.; Schendel, D.E.; Croen, L.A.; Chopra, P.; Alisch, R.S.; Newschaffer, C.J.; Warren, S.T.; et al. Case-control meta-analysis of blood DNA methylation and autism spectrum disorder. Mol. Autism. 2018, 9, 40. [CrossRef] [PubMed]

33. Ducker, G.S.; Rabinowitz, J.D. One-carbon metabolism in health and disease. Cell Metab. 2017, $25,27-42$. [CrossRef] [PubMed]

34. Zhang, N. Role of methionine on epigenetic modification of DNA methylation and gene expression in animals. Anim. Nutr. 2018, 4, 11-16. [CrossRef]

35. Langley-Evans, S.C. Nutrition in early life and the programming of adult disease: A review. J. Hum. Nutr. Diet. 2015, 28, 1-14. [CrossRef]

36. Jiménez-Chillarón, J.C.; Díaz, R.; Martínez, D.; Pentinat, T.; Ramón-Krauel, M.; Ribó, S.; Plösch, T. The role of nutrition on epigenetic modifications and their implications on health. Biochimie 2012, 94, 2242-2263. [CrossRef]

37. Dolinoy, D.C.; Weidman, J.R.; Waterland, R.A.; Jirtle, R.L. Maternal genistein alters coat color and protects Avy mouse offspring from obesity by modifying the fetal epigenome. Env. Health Perspect. 2006, 114, 567-572. [CrossRef]

38. Cropley, J.E.; Suter, C.M.; Beckman, K.B.; Martin, D.I. Germ-line epigenetic modification of the murine Avy allele by nutritional supplementation. Proc. Natl. Acad. Sci. USA 2006, 103, 17308-17312. [CrossRef]

39. Rees, W.D.; Hay, S.M.; Brown, D.S.; Antipatis, C.; Palmer, R.M. Maternal protein deficiency causes hypermethylation of DNA in the livers of rat fetuses. J. Nutr. 2000, 130, 1821-1826. [CrossRef]

40. Lillycrop, K.A.; Slater-Jefferies, J.L.; Hanson, M.A.; Godfrey, K.M.; Jackson, A.A.; Burdge, G.C. Induction of altered epigenetic regulation of the hepatic glucocorticoid receptor in the offspring of rats fed a proteinrestricted diet during pregnancy suggests that reduced DNA methyltransferase- 1 expression is involved in impaired DNA methylation and changes in histone modifications. Br. J. Nutr. 2007, 97, 1064-1073.

41. Lillycrop, K.A.; Phillips, E.S.; Torrens, C.; Hanson, M.A.; Jackson, A.A.; Burdge, G.C. Feeding pregnant rats a protein-restricted diet persistently alters the methylation of specific cytosines in the hepatic PPAR alpha promoter of the offspring. Br. J. Nutr. 2008, 100, 278-282. [CrossRef] [PubMed]

42. Van Straten, E.M.; Bloks, V.W.; Huijkman, N.C.; Baller, J.F.; van Meer, H.; Lütjohann, D.; Kuipers, F.; Plösch, T. The liver X-receptor gene promoter is hypermethylated in a mouse model of prenatal protein restriction. Am. J. Physiol. Regul. Integr. Comp. Physiol. 2010, 298, 275-282. [CrossRef] [PubMed]

43. Sandovici, I.; Smith, N.H.; Nitert, M.D.; Ackers-Johnson, M.; Uribe-Lewis, S.; Ito, Y.; Jones, R.H.; Marquez, V.E.; Cairns, W.; Tadayyon, M.; et al. Maternal diet and aging alter the epigenetic control of a promoter-enhancer interaction at the Hnf4a gene in rat pancreatic islets. Proc. Natl. Acad. Sci. USA 2011, 108, 5449-5454. [CrossRef] [PubMed]

44. Coupé, B.; Amarger, V.; Grit, I.; Benani, A.; Parnet, P. Nutritional programming affects hypothalamic organization and early response to leptin. Endocrinology 2010, 151, 702-713. [CrossRef] [PubMed]

45. Jousse, C.; Parry, L.; Lambert-Langlais, S.; Maurin, A.C.; Averous, J.; Bruhat, A.; Carraro, V.; Tost, J.; Letteron, P.; Chen, P.; et al. Perinatal undernutrition affects the methylation and expression of the leptin gene in adults: Implication for the understanding of metabolic syndrome. FASEB J. 2011, 25, 3271-3278. [CrossRef] [PubMed]

46. Watkins, A.J.; Dias, I.; Tsuro, H.; Allen, D.; Emes, R.D.; Moreton, J.; Wilson, R.; Ingram, R.J.M.; Sinclair, K.D. Paternal diet programs offspring health through sperm- and seminal plasma-specific pathways in mice. Proc. Natl. Acad. Sci. USA 2018, 115, 10064-10069. [CrossRef] [PubMed]

47. Zhang, S.; Rattanatray, L.; MacLaughlin, S.M.; Cropley, J.E.; Suter, C.M.; Molloy, L.; Kleemann, D.; Walker, S.K.; Muhlhausler, B.S.; Morrison, J.L.; et al. Periconceptional undernutrition in normal and overweight ewes leads to increased adrenal growth and epigenetic changes in adrenal IGF2/H19 gene in offspring. FASEB J. 2010, 24, 2772-2782. [CrossRef] [PubMed]

48. Perkins, E.; Murphy, S.K.; Murtha, A.P.; Schildkraut, J.; Jirtle, R.L.; Demark-Wahnefried, W.; Forman, M.R.; Kurtzberg, J.; Overcash, F.; Huang, Z.; et al. Insulin-like growth factor 2/H19 methylation at birth and risk of overweight and obesity in children. J. Pediatr. 2012, 161, 31-39. [CrossRef] 
49. Nijland, M.J.; Mitsuya, K.; Li, C.; Ford, S.; McDonald, T.J.; Nathanielsz, P.W.; Cox, L.A. Epigenetic modification of fetal baboon hepatic phosphoenolpyruvate carboxykinase following exposure to moderately reduced nutrient availability. J. Physiol. 2010, 588 Pt 8, 1349-1359. [CrossRef]

50. Heijmans, B.T.; Tobi, E.W.; Stein, A.D.; Putter, H.; Blauw, G.J.; Susser, E.S.; Slagboom, P.E.; Lumey, L.H. Persistent epigenetic differences associated with prenatal exposure to famine in humans. Proc. Natl. Acad. Sci. USA 2008, 105, 17046-17049. [CrossRef]

51. Tobi, E.W.; Lumey, L.H.; Talens, R.P.; Kremer, D.; Putter, H.; Stein, A.D.; Slagboom, P.E.; Heijmans, B.T. DNA methylation differences after exposure to prenatal famine are common and timing- and sex-specific. Hum. Mol. Genet. 2009, 18, 4046-4053. [CrossRef]

52. Di Francesco, A.; Di Germanio, C.; Bernier, M.; de Cabo, R. A time to fast. Science 2018, 362, $770-775$. [CrossRef]

53. Campión, J.; Milagro, F.I.; Goyenechea, E.; Martínez, J.A. TNF-alpha promoter methylation as a predictive biomarker for weight-loss response. Obesity 2009, 17, 1293-1297.

54. Milagro, F.I.; Mansego, M.L.; De Miguel, C.; Martínez, J.A. Dietary factors, epigenetic modifications and obesity outcomes: Progresses and perspectives. Mol. Asp. Med. 2013, 34, 782-812. [CrossRef]

55. Bouchard, L.; Rabasa-Lhoret, R.; Faraj, M.; Lavoie, M.E.; Mill, J.; Pérusse, L.; Vohl, M.C. Differential epigenomic and transcriptomic responses in subcutaneous adipose tissue between low and high responders to caloric restriction. Am. J. Clin. Nutr. 2010, 91, 309-320. [CrossRef]

56. Jørgensen, S.W.; Brøns, C.; Bluck, L.; Hjort, L.; Færch, K.; Thankamony, A.; Gillberg, L.; Friedrichsen, M.; Dunger, D.B.; Vaag, A.A. Metabolic response to 36 hours of fasting in young men born small vs. appropriate for gestational age. Diabetologia 2015, 58, 178-187. [CrossRef]

57. Hjort, L.; Jørgensen, S.W.; Gillberg, L.; Hall, E.; Brøns, C.; Frystyk, J.; Vaag, A.A.; Ling, C. 36 h fasting of young men influences adipose tissue DNA methylation of LEP and ADIPOQ in a birth weight-dependent manner. Clin. Epigenetics 2017, 9, 40. [CrossRef]

58. Samblas, M.; Milagro, F.I.; Martínez, A. DNA methylation markers in obesity, metabolic syndrome, and weight loss. Epigenetics 2019, 14, 421-444. [CrossRef]

59. Vucetic, Z.; Kimmel, J.; Totoki, K.; Hollenbeck, E.; Reyes, T.M. Maternal high-fat diet alters methylation and gene expression of dopamine and opioid-related genes. Endocrinology 2010, 151, 4756-4764. [CrossRef]

60. Ehara, T.; Kamei, Y.; Yuan, X.; Takahashi, M.; Kanai, S.; Tamura, E.; Tsujimoto, K.; Tamiya, T.; Nakagawa, Y.; Shimano, H.; et al. Ligand-activated PPAR $\alpha$-dependent DNA demethylation regulates the fatty acid $\beta$-oxidation genes in the postnatal liver. Diabetes 2015, 64, 775-784. [CrossRef]

61. Yuan, X.; Tsujimoto, K.; Hashimoto, K.; Kawahori, K.; Hanzawa, N.; Hamaguchi, M.; Seki, T.; Nawa, M.; Ehara, T.; Kitamura, Y.; et al. Epigenetic modulation of Fgf21 in the perinatal mouse liver ameliorates diet-induced obesity in adulthood. Nat. Commun. 2018, 9, 636. [CrossRef] [PubMed]

62. BonDurant, L.D.; Ameka, M.; Naber, M.C.; Markan, K.R.; Idiga, S.O.; Acevedo, M.R.; Walsh, S.A.; Ornitz, D.M.; Potthoff, M.J. FGF21 Regulates metabolism through adipose-dependent and -independent mechanisms. Cell Metab. 2017, 25, 935.e4-944.e4. [CrossRef] [PubMed]

63. Butruille, L.; Marousez, L.; Pourpe, C.; Oger, F.; Lecoutre, S.; Catheline, D.; Görs, S.; Metges, C.C.; Guinez, C.; Laborie, C.; et al. Maternal high-fat diet during suckling programs visceral adiposity and epigenetic regulation of adipose tissue stearoyl-CoA desaturase-1 in offspring. Int J. Obes. 2019. [CrossRef]

64. Kim, A.Y.; Park, Y.J.; Pan, X.; Shin, K.C.; Kwak, S.H.; Bassas, A.F.; Sallam, R.M.; Park, K.S.; Alfadda, A.A.; $\mathrm{Xu}, \mathrm{A}$; et al. Obesity-induced DNA hypermethylation of the adiponectin gene mediates insulin resistance. Nat. Commun. 2015, 6, 7585. [CrossRef] [PubMed]

65. Raciti, G.A.; Spinelli, R.; Desiderio, A.; Longo, M.; Parrillo, L.; Nigro, C.; D’Esposito, V.; Mirra, P.; Fiory, F.; Pilone, V.; et al. Specific CpG hyper-methylation leads to Ankrd26 gene down-regulation in white adipose tissue of a mouse model of diet-induced obesity. Sci. Rep. 2017, 7, 43526. [CrossRef] [PubMed]

66. Gillberg, L.; Perfilyev, A.; Brøns, C.; Thomasen, M.; Grunnet, L.G.; Volkov, P.; Rosqvist, F.; Iggman, D.; Dahlman, I.; Risérus, U.; et al. Adipose tissue transcriptomics and epigenomics in low birthweight men and controls: Role of high-fat overfeeding. Diabetologia 2016, 59, 799-812. [CrossRef] [PubMed]

67. Jacobsen, S.C.; Brøns, C.; Bork-Jensen, J.; Ribel-Madsen, R.; Yang, B.; Lara, E.; Hall, E.; Calvanese, V.; Nilsson, E.; Jørgensen, S.W.; et al. Effects of short-term high-fat overfeeding on genome-wide DNA methylation in the skeletal muscle of healthy young men. Diabetologia 2012, 55, 3341-3349. [CrossRef] [PubMed] 
68. Brøns, C.; Jacobsen, S.C.; Nilsson, E.; Ronn, T.; Jensen, C.B.; Storgaard, H.; Poulsen, P.; Groop, L.; Ling, C.; Asturp, A.; et al. Deoxyribonucleic acid methylation and gene expression of PPARGC1A in human muscle is influenced by high-fat overfeeding in a birth-weight-dependent manner. J. Clin. Endocrinol. Metab. 2010, 95, 3048-3056. [CrossRef] [PubMed]

69. Ludwig, D.S.; Willett, W.C.; Volek, J.S.; Neuhouser, M.L. Dietary fat: From foe to friend? Science 2018, 362, 764-770. [CrossRef] [PubMed]

70. Perfilyev, A.; Dahlman, I.; Gillberg, L.; Rosqvist, F.; Iggman, D.; Volkov, P.; Nilsson, E.; Risérus, U.; Ling, C. Impact of polyunsaturated and saturated fat overfeeding on the DNA-methylation pattern in human adipose tissue: A randomized controlled trial. Am. J. Clin. Nutr. 2017, 105, 991-1000. [CrossRef] [PubMed]

71. Hall, E.; Volkov, P.; Dayeh, T.; Bacos, K.; Rönn, T.; Nitert, M.D.; Ling, C. Effects of palmitate on genome-wide mRNA expression and DNA methylation patterns in human pancreatic islets. BMC Med. 2014, 12, 103. [CrossRef] [PubMed]

72. Willmer, T.; Johnson, R.; Louw, J.; Pheiffer, C. Blood-based DNA methylation biomarkers for type 2 diabetes: Potential for clinical applications. Front. Endocrinol. 2018, 9, 744. [CrossRef] [PubMed]

73. Oussalah, A.; Rischer, S.; Bensenane, M.; Conroy, G.; Filhine-Tresarrieu, P.; Debard, R.; Forest-Tramoy, D.; Josse, T.; Reinicke, D.; Garcia, M.; et al. Plasma mSEPT9: A novel circulating cell-free DNA-based epigenetic biomarker to diagnose hepatocellular carcinoma. EBioMedicine 2018, 30, 138-147. [CrossRef] [PubMed]

74. Gillberg, L.; Ling, C. The potential use of DNA methylation biomarkers to identify risk and progression of type 2 diabetes. Front. Endocrinol. 2015, 6, 43. [CrossRef] [PubMed]

75. Godfrey, K.M.; Sheppard, A.; Gluckman, P.D.; Lillycrop, K.A.; Burdge, G.C.; McLean, C.; Rodford, J.; Slater-Jefferies, J.L.; Garratt, E.; Crozier, S.R.; et al. Epigenetic gene promoter methylation at birth is associated with child's later adiposity. Diabetes 2011, 60, 1528-1534. [CrossRef] [PubMed]

76. Toperoff, G.; Aran, D.; Kark, J.D.; Rosenberg, M.; Dubnikov, T.; Nissan, B.; Wainstein, J.; Friedlander, Y.; Levy-Lahad, E.; Glaser, B.; et al. Genome-wide survey reveals predisposing diabetes type 2-related DNA methylation variations in human peripheral blood. Hum. Mol. Genet. 2012, 21,371-383. [CrossRef] [PubMed]

77. Smemo, S.; Tena, J.J.; Kim, K.H.; Gamazon, E.R.; Sakabe, N.J.; Gómez-Marín, C.; Aneas, I.; Credidio, F.L.; Sobreira, D.R.; Wasserman, N.F.; et al. Obesity-associated variants within FTO form long-range functional connections with IRX3. Nature 2014, 20, 371-375. [CrossRef]

78. Sharp, G.C.; Lawlor, D.A.; Richmond, R.C.; Fraser, A.; Simpkin, A.; Suderman, M.; Shihab, H.A.; Lyttleton, O.; McArdle, W.; Ring, S.M.; et al. Maternal pre-pregnancy BMI and gestational weight gain, offspring DNA methylation and later offspring adiposity: Findings from the Avon longitudinal study of parents and children. Int. J. Epidemiol. 2015, 44, 1288-1304. [CrossRef]

79. Dalgaard, K.; Landgraf, K.; Heyne, S.; Lempradl, A.; Longinotto, J.; Gossens, K.; Ruf, M.; Orthofer, M.; Strogantsev, R.; Selvaraj, M.; et al. Trim28 haploinsufficiency triggers bi-stable epigenetic obesity. Cell 2016, 164, 353-364. [CrossRef]

80. Rhee, J.K.; Lee, J.H.; Yang, H.K.; Kim, T.M.; Yoon, K.H. DNA Methylation profiles of blood cells are distinct between early-onset obese and control individuals. Genom. Inf. 2017, 15, 28-37. [CrossRef]

81. Dick, K.J.; Nelson, C.P.; Tsaprouni, L.; Sandling, J.K.; Aïssi, D.; Wahl, S.; Meduri, E.; Morange, P.E.; Gagnon, F.; Grallert, H.; et al. DNA methylation and body-mass index: A genome-wide analysis. Lancet 2014, 383, 1990-1998. [CrossRef]

82. Chambers, J.C.; Loh, M.; Lehne, B.; Drong, A.; Kriebel, J.; Motta, V.; Wahl, S.; Elliott, H.R.; Rota, F.; Scott, W.R.; et al. Epigenome-wide association of DNA methylation markers in peripheral blood from Indian Asians and Europeans with incident type 2 diabetes: A nested case-control study. Lancet Diabetes Endocrinol. 2015, 3, 526-534. [CrossRef]

83. Dayeh, T.; Tuomi, T.; Almgren, P.; Perfilyev, A.; Jansson, P.A.; de Mello, V.D.; Pihlajamäki, J.; Vaag, A.; Groop, L.; Nilsson, E.; et al. DNA methylation of loci within ABCG1 and PHOSPHO1 in blood DNA is associated with future type 2 diabetes risk. Epigenetics 2016, 11, 482-488. [CrossRef] [PubMed]

84. Kriebel, J.; Herder, C.; Rathmann, W.; Wahl, S.; Kunze, S.; Molnos, S.; Volkova, N.; Schramm, K.; Carstensen-Kirberg, M.; Waldenberger, M.; et al. Association between DNA methylation in whole blood and measures of glucose metabolism: KORA F4 study. PLoS ONE 2016, 11, e0152314. [CrossRef] [PubMed] 
85. Walaszczyk, E.; Luijten, M.; Spijkerman, A.M.W.; Bonder, M.J.; Lutgers, H.L.; Snieder, H.; Wolffenbuttel, B.H.R.; van Vliet-Ostaptchouk, J.V. DNA methylation markers associated with type 2 diabetes, fasting glucose and HbA1c levels: A systematic review and replication in a case-control sample of the lifelines study. Diabetologia 2018, 61, 354-368. [CrossRef]

86. Yvan-Charvet, L.; Wang, N.; Tall, A.R. Role of HDL, ABCA1, and ABCG1 transporters in cholesterol efflux and immune responses. Arter. Thromb. Vasc. Biol. 2010, 30, 139-143. [CrossRef]

87. Bacos, K.; Gillberg, L.; Volkov, P.; Olsson, A.H.; Hansen, T.; Pedersen, O.; Gjesing, A.P.; Eiberg, H.; Tuomi, T.; Almgren, P.; et al. Blood-based biomarkers of age-associated epigenetic changes in human islets associate with insulin secretion and diabetes. Nat. Commun. 2016, 7, 11089. [CrossRef]

88. Wahl, S.; Drong, A.; Lehne, B.; Loh, M.; Scott, W.R.; Kunze, S.; Tsai, P.-C.; Ried, J.S.; Zhang, W.; Yang, Y.; et al. Epigenome-wide association study of body mass index, and the adverse outcomes of adiposity. Nature 2017, 541, 81-86. [CrossRef]

89. Cordero, P.; Campion, J.; Milagro, F.I.; Goyenechea, E.; Steemburgo, T.; Javierre, B.M.; Martinez, J.A. Leptin and TNF- $\alpha$ promoter methylation levels measured by MSP could predict the response to a low-calorie diet. J. Physiol. Biochem. 2011, 67, 463-470. [CrossRef]

90. Huang, Y.T.; Maccani, J.Z.J.; Hawley, N.L.; Wing, R.R.; Kelsey, K.T.; McCaffery, J.M. Epigenetic patterns in successful weight loss maintainers: A pilot study. Int J. Obes. 2015, 39, 865-868. [CrossRef]

91. Nicoletti, C.F.; Nonino, C.B.; de Oliveira, B.A.; Pinhel, M.A.; Mansego, M.L.; Milagro, F.I.; Zulet, M.A.; Martinez, J.A. DNA methylation and hydroxymethylation levels in relation to two weight loss strategies: Energy-restricted diet or bariatric surgery. Obes. Surg. 2016, 26, 603-611. [CrossRef] [PubMed]

92. McEwen, L.M.; Gatev, E.G.; Jones, M.J.; MacIsaac, J.L.; McAllister, M.M.; Goulding, R.E.; Madden, K.M.; Dawes, M.G.; Kobor, M.S.; Ashe, M.C. DNA methylation signatures in peripheral blood mononuclear cells from a lifestyle intervention for women at midlife: A pilot randomized controlled trial. Appl. Physiol. Nutr. Metab. 2018, 43, 233-239. [CrossRef] [PubMed]

93. Stathis, A.; Hotte, S.J.; Chen, E.X.; Hirte, H.W.; Oza, A.M.; Moretto, P.; Webster, S.; Laughlin, A.; Stayner, L.A.; McGill, S.; et al. Phase I study of decitabine in combination with vorinostat in patients with advanced solid tumors and non-Hodgkin's lymphomas. Clin. Cancer Res. 2009, 27, 3528. [CrossRef] [PubMed]

94. Lundh, M.; Galbo, T.; Poulsen, S.S.; Mandrup-Poulsen, T. Histone deacetylase 3 inhibition improves glycaemia and insulin secretion in obese diabetic rats. Diabetes Obes. Metab. 2015, 17, 703-707. [CrossRef] [PubMed]

95. Daneshpajooh, M.; Eliasson, L.; Bacos, K.; Ling, C. MC1568 improves insulin secretion in islets from type 2 diabetes patients and rescues $\beta$-cell dysfunction caused by Hdac7 upregulation. Acta Diabetol. 2018, 55, 1231-1235. [CrossRef] [PubMed]

96. Daneshpajooh, M.; Bacos, K.; Bysani, M.; Bagge, A.; Ottosson Laakso, E.; Vikman, P.; Eliasson, L.; Mulder, H.; Ling, C. HDAC7 is overexpressed in human diabetic islets and impairs insulin secretion in rat islets and clonal beta cells. Diabetologia 2017, 60, 116-125. [CrossRef] [PubMed]

97. Zuo, S.; Fries, B.E.; Szafara, K.; Regal, R. Valproic Acid as a potentiator of metabolic syndrome in institutionalized residents on concomitant antipsychotics: Fat chance, or slim to none? Pharm. Ther. 2015, 40, 126-132.

98. Avery, L.B.; Bumpus, N.N. Valproic acid is a novel activator of AMP-activated protein kinase and decreases liver mass, hepatic fat accumulation, and serum glucose in obese mice. Mol. Pharm. 2014, 85, 1-10. [CrossRef]

99. Bridgeman, S.C.; Ellison, G.C.; Melton, P.E.; Newsholme, P.; Mamotte, C.D.S. Epigenetic effects of metformin: From molecular mechanisms to clinical implications. Diabetes Obes. Metab. 2018, 20, 1553-1562. [CrossRef]

100. Timp, W.; Feinberg, A.P. Cancer as a dysregulated epigenome allowing cellular growth advantage at the expense of the host. Nat. Rev. Cancer. 2013, 13, 497-510. [CrossRef]

101. Kirchner, H.; Sinha, I.; Gao, H.; Ruby, M.A.; Schönke, M.; Lindvall, J.M.; Barrès, R.; Krook, A.; Näslund, E.; Dahlman-Wright, K.; et al. Altered DNA methylation of glycolytic and lipogenic genes in liver from obese and type 2 diabetic patients. Mol. Metab. 2016, 5, 171-183. [CrossRef] [PubMed]

(C) 2019 by the authors. Licensee MDPI, Basel, Switzerland. This article is an open access article distributed under the terms and conditions of the Creative Commons Attribution (CC BY) license (http://creativecommons.org/licenses/by/4.0/). 